\title{
Structural characterization and DNA binding properties of a new imine compound
}

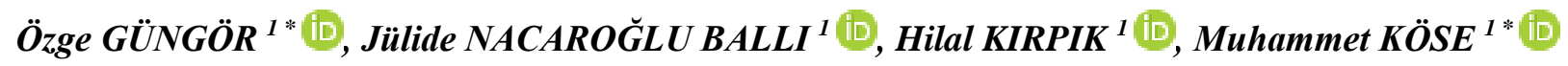 \\ ${ }^{1}$ Kahramanmaras Sutcu Imam University, Chemistry Deparment, Kahramanmaras, Turkey
}

\begin{abstract}
In this study, a new imine compound (M) was prepared from the reaction of $o$-vanillin and 4isopropylaniline. The structure of the compound was characterized by the spectroscopic and analytical methods. Single crystals of the compound were grown and solid-state structure of the compound was further characterized by X-ray diffraction study. The UV-Vis absorption and emission properties of the compound were studied in different solvents. Moreover, DNA binding ability of the compound was investigated and compared with the standard DNA binding agents. The compound showed similar binding constant $\left(4 \times 10^{5} \mathrm{M}^{-1}\right)$ to those spermine and ethidiumbromide.
\end{abstract}

\section{Article info \\ History:}

Received:22.07.2019

Accepted:17.04.2019

Keywords:

Imine,

Absorption,

Emission,

X-ray,

DNA binding

\section{Introduction}

Imine compounds also called as Schiff bases contain a characteristic $\mathrm{C}=\mathrm{N}$ double bond. They are prepared from the reaction of primary amines with an aldehyde or a ketone [1]. Imine compounds are the nitrogen analogue of an aldehyde or ketone in which the carbonyl group has been replaced by an imine group. They are widely used as organic compounds and their chemistry attracts great attention due to their ability to form complexes with metal ions and have a wide variety of applications in many fields such as analytical, biological and inorganic chemistry. Some of them have pharmacological properties including toxicity against bacterial/fungal growth, anticancer and antitumor activity [2-5].

DNA chains are composed of units called genes that are responsible for synthesizing specific proteins. DNA is an important biomolecule and has crucial roles in biological process such as long-term storage of information, identification of hereditary characteristics, and reproduction of genetic information [6].

The linking and interaction of newly synthesized small molecules with DNA is also important in the design of new drugs as well as in the development of DNA detection methods [7]. The interaction of DNA with drug molecules is particularly important to determine the interaction with drug molecules with anticarcinogenic properties of a specific molecule [8].

\section{Method}

\subsection{General}

Starting materials (4-isopropylaniline and o-vanillin) and solvents were purchased from Sigma Aldrich and used as received. FT-IR spectra were measured on a Perkin Elmer Spectrum 100 FT-IR. The electronic spectra were taken on a Perkin Elmer Lambda 45 spectrophotometer. The fluorescence spectra were obtained on a Perkin Elmer LS55 luminescence spectrometer.

\subsection{Synthesis of the compound (M)}

4-isopropylaniline (1 mmol) and o-vanillin (1 mmol) were mixed in ethanol $(40 \mathrm{~mL})$. The resulting red-clear solution was refluxed for two hours. The completion of the reaction was followed by T.L.C. and the volume of the solution was reduced $20 \mathrm{~mL}$ on a rotary evaporator. The red-coloured crystals were obtained from slow evaporation in a few days.

M: $\mathrm{C}_{17} \mathrm{H}_{19} \mathrm{NO}_{2}$ : Yield: $82 \%$, color: red, melting point: $52{ }^{\circ} \mathrm{C}$. Elemental Analysis (\%): Found (Calcd.): C, 75.62 (75.81\%); H, 6.81 (7.11\%); N, 5.03(5.20). ${ }^{1} \mathrm{H}-$ $\mathrm{NMR}\left(\mathrm{ppm} ; \mathrm{CDCl}_{3}\right): 13.25(b, 1 \mathrm{H}, \mathrm{OH}), 8.44(s, 1 \mathrm{H}$, $\mathrm{CH}=\mathrm{N}), 6.87-7.55(m, 7 \mathrm{H}, \mathrm{Ar}-\mathrm{H}), 3.83\left(s, 3 \mathrm{H}, \mathrm{OCH}_{3}\right)$, 
2.72 (septet, 1H, CHisopropyl), $1.25(d, 6 \mathrm{H}$, $\mathrm{CH}_{3}$ isopropyl), ${ }^{13} \mathrm{C}-\mathrm{NMR}$ (d, ppm; $\mathrm{CDCl}_{3}$ ): 160.11 ($\mathrm{C}=\mathrm{N}), 115-150(\mathrm{Ar}-\mathrm{C}), 58.73\left(\mathrm{OCH}_{3}\right), 34.2$ and 22.2

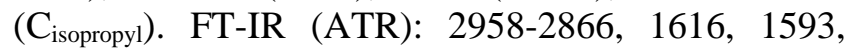
1461, 1443, 1410, 1359, 1273, 1249, 1200, 1178, 1075, $968,851,778,735,563 \mathrm{~cm}^{-1}$.

\subsection{X-ray structure solution and refinement for the compound}

Single crystals for X-ray diffraction study were grown by recrystallization of a chloroform solution of the compound. A single crystal of dimensions $0.26 \times$ $0.25 \times 0.10 \mathrm{~mm}^{3}$ was mounted on the diffractometer. Data were collected at 293(2) K on a Bruker ApexII CCD diffractometer using Mo-K $\alpha$ radiation (l= $0.71073 \AA$ ). The structure was solved by direct methods and refined on $F^{2}$ using all the reflections [9, 10]. All the non-hydrogen atoms were refined using anisotropic atomic displacement parameters and hydrogen atoms bonded to carbon atoms were inserted at calculated positions using a riding model.

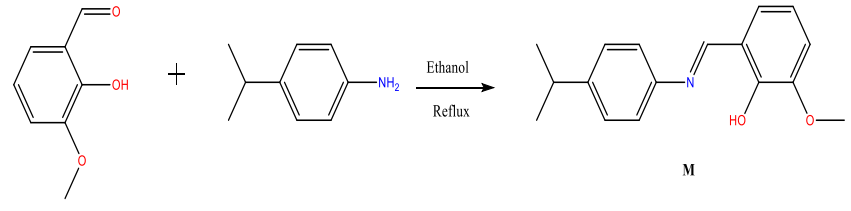

Figure 1. Synthesis of the compound (M).

\section{Results and Discussion}

In the course of this work, a new imine compound was prepared and its DNA binding ability was determined by spectroscopic method. The compound (Figure 1) was prepared by Schiff base condensation reaction of one equivalent $o$-vanillin and one equivalent 4isopropylaniline in ethanol. The compound was characterized by the spectroscopic and analytical methods. FT-IR spectrum of the compound is shown in Figure 2. The characteristic $v(\mathrm{C}=\mathrm{N})$ bond stretching was observed as a sharp peak at $1616 \mathrm{~cm}^{-1}$ confirming the formation of the compound. The stretching's in the range of $2866-2926 \mathrm{~cm}^{-1}$ are due to the $v(\mathrm{C}-\mathrm{H})$ stretching's.

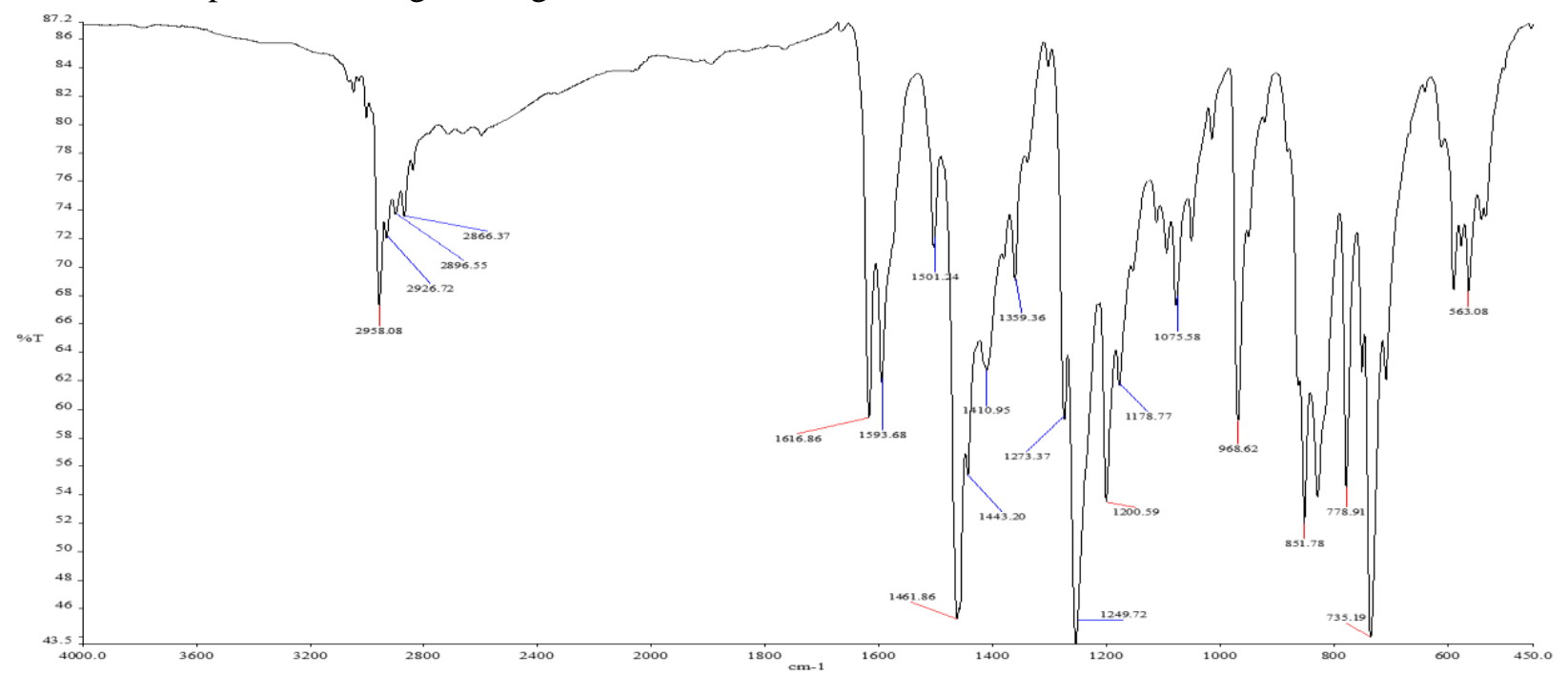

Figure 2. FT-IR spectrum of compound.

Single crystals of the compound were obtained from slow evaporation of ethanol solution of the compound. Thus, structure of the compound was determined by X-ray diffraction study. X-ray crystallographic data for the compound is listed in Table 1. Bond lengths and angles are given in Table 2 and Table 3. X-ray structure of the compound is shown in Figure 3.

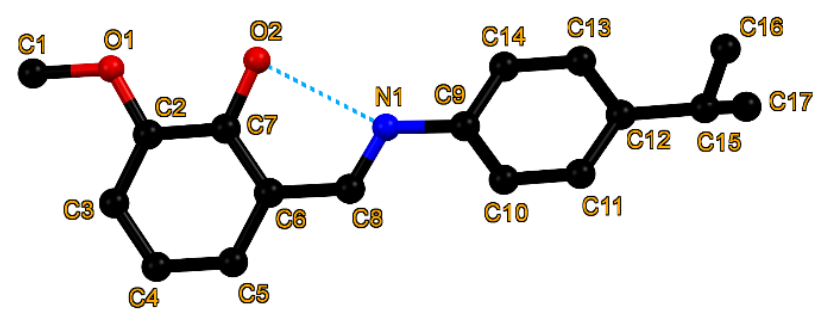

Figure $3 \mathrm{X}$-ray structure of the compound.

$\mathrm{X}$-ray crystallographic data revealed that the asymmetric unit contain a molecule with no crystallographically imposed symmetry. In the structure of the compound, the N1-C8 bond distance is 1.277(5) $\AA$ and within the range of $\mathrm{C}=\mathrm{N}$ bond distance. 
This confirms that the compound favours the enolimine tautomeric form in the solid state. In the structure of the compound, as expected, a phenol-imine intramolecular hydrogen bond $(\mathrm{O} 2 \cdots \mathrm{N} 1)$ was observed. The phenyl and phenol rings are located in trans conformation with respect to the imine bond. The intermolecular contacts which stabilise crystal structure of the compound were investigated by using Hirshfeld surface analysis. The 2D fingerprints plot of the compound showing the different intermolecular contacts are shown in Figure 4. The fingerprint plot showed high intensities for di and de values between 1.2 and $1.8 \AA$. The main contribution comes from $\mathrm{H} \cdots \mathrm{H}$ contacts followed by $\mathrm{C} \cdots \mathrm{H} / \mathrm{H} \cdots \mathrm{C}$ and $\mathrm{O} \cdots \mathrm{H} / \mathrm{H} \cdots \mathrm{O}$ contacts. The $\mathrm{O} \cdots \mathrm{H} / \mathrm{H} \cdots \mathrm{O}$ contacts were observed as red-spots in the dn surface of the compound (Figure 5).

Table 1. Crystallographic data for the compound.

\begin{tabular}{|c|c|}
\hline Identification code & $\mathrm{M}$ \\
\hline Empirical formula & $\mathrm{C}_{17} \mathrm{H}_{19} \mathrm{NO}_{2}$ \\
\hline Crystal size $/ \mathrm{mm}^{3}$ & $0.12 \times 0.11 \times 0.09$ \\
\hline Formule weight & 269.33 \\
\hline Crystal system & Monoclinic \\
\hline Space group & $\mathrm{P} 2{ }_{1} / \mathrm{n}$ \\
\hline Unit cell & $13.5624(13)$ \\
\hline $\mathrm{b} / \AA$ & $7.5355(7)$ \\
\hline $\mathrm{c} / \AA$ & $14.6976(13)$ \\
\hline$\alpha /^{\circ}$ & 90 \\
\hline$\beta /{ }^{\circ}$ & $90.426(5)$ \\
\hline$\gamma /{ }^{\circ}$ & 90 \\
\hline Volume $/ \AA^{3}$ & $1502.0(2)$ \\
\hline $\mathrm{Z}$ & 4 \\
\hline Abs. Coeff. $\left(\mathrm{mm}^{-1}\right)$ & 0.078 \\
\hline Refl. collected & 25987 \\
\hline R1, WR2 [I $>=2 \sigma(\mathrm{I})]$ & $0.0990,0.1756$ \\
\hline R1, WR2 [all data] & $0.1579,0.2011$ \\
\hline \multicolumn{2}{|c|}{ Largest diff. peak/hole/e $\AA^{-3} 0.20 /-0.26$} \\
\hline CCDC number & 1905445 \\
\hline
\end{tabular}

Table 2 Bond lengths for compound

\begin{tabular}{llll}
\hline Bond & Length $/ \AA$ & Bond & Length/ $\AA$ \\
\hline $\mathrm{O}(1)-\mathrm{C}(1)$ & $1.422(5)$ & $\mathrm{C}(6)-\mathrm{C}(8)$ & $1.445(5)$ \\
$\mathrm{O}(1)-\mathrm{C}(2)$ & $1.365(4)$ & $\mathrm{C}(9)-\mathrm{C}(10)$ & $1.385(5)$ \\
$\mathrm{O}(2)-\mathrm{C}(7)$ & $1.349(4)$ & $\mathrm{C}(9)-\mathrm{C}(14)$ & $1.376(5)$ \\
$\mathrm{N}(1)-\mathrm{C}(8)$ & $1.277(5)$ & $\mathrm{C}(10)-\mathrm{C}(11)$ & $1.370(5)$ \\
$\mathrm{N}(1)-\mathrm{C}(9)$ & $1.413(5)$ & $\mathrm{C}(11)-\mathrm{C}(12)$ & $1.382(5)$ \\
$\mathrm{C}(2)-\mathrm{C}(3)$ & $1.374(5)$ & $\mathrm{C}(12)-\mathrm{C}(13)$ & $1.391(5)$ \\
$\mathrm{C}(2)-\mathrm{C}(7)$ & $1.391(5)$ & $\mathrm{C}(12)-\mathrm{C}(15)$ & $1.513(6)$ \\
$\mathrm{C}(3)-\mathrm{C}(4)$ & $1.380(6)$ & $\mathrm{C}(13)-\mathrm{C}(14)$ & $1.374(5)$ \\
$\mathrm{C}(4)-\mathrm{C}(5)$ & $1.363(6)$ & $\mathrm{C}(15)-\mathrm{C}(16)$ & $1.463(7)$ \\
$\mathrm{C}(5)-\mathrm{C}(6)$ & $1.401(5)$ & $\mathrm{C}(15)-\mathrm{C}(17)$ & $1.487(6)$ \\
$\mathrm{C}(6)-\mathrm{C}(7)$ & $1.398(5)$ & & \\
\hline
\end{tabular}

Table 3 Bond angles for compound.

\begin{tabular}{cccc}
\hline Bond & Angle $^{\circ}$ & Bond & Angle $/^{\circ}$ \\
\hline $\mathrm{C}(2)-\mathrm{O}(1)-\mathrm{C}(1)$ & $116.8(3)$ & $\mathrm{N}(1)-\mathrm{C}(8)-\mathrm{C}(6)$ & $123.2(3)$ \\
$\mathrm{C}(8)-\mathrm{N}(1)-\mathrm{C}(9)$ & $121.1(3)$ & $\mathrm{C}(10)-\mathrm{C}(9)-\mathrm{N}(1)$ & $124.1(4)$ \\
$\mathrm{O}(1)-\mathrm{C}(2)-\mathrm{C}(3)$ & $124.6(4)$ & $\mathrm{C}(14)-\mathrm{C}(9)-\mathrm{N}(1)$ & $117.8(3)$ \\
$\mathrm{O}(1)-\mathrm{C}(2)-\mathrm{C}(7)$ & $115.6(3)$ & $\mathrm{C}(14)-\mathrm{C}(9)-\mathrm{C}(10)$ & $118.1(4)$ \\
$\mathrm{C}(3)-\mathrm{C}(2)-\mathrm{C}(7)$ & $119.8(4)$ & $\mathrm{C}(11)-\mathrm{C}(10)-\mathrm{C}(9)$ & $120.6(4)$ \\
$\mathrm{C}(2)-\mathrm{C}(3)-\mathrm{C}(4)$ & $120.5(4)$ & $\mathrm{C}(10)-\mathrm{C}(11)-\mathrm{C}(12)$ & $122.0(4)$ \\
$\mathrm{C}(5)-\mathrm{C}(4)-\mathrm{C}(3)$ & $120.4(4)$ & $\mathrm{C}(11)-\mathrm{C}(12)-\mathrm{C}(13)$ & $117.0(4)$ \\
$\mathrm{C}(4)-\mathrm{C}(5)-\mathrm{C}(6)$ & $120.6(4)$ & $\mathrm{C}(11)-\mathrm{C}(12)-\mathrm{C}(15)$ & $121.6(4)$ \\
$\mathrm{C}(5)-\mathrm{C}(6)-\mathrm{C}(8)$ & $120.0(4)$ & $\mathrm{C}(13)-\mathrm{C}(12)-\mathrm{C}(15)$ & $121.4(4)$ \\
$\mathrm{C}(7)-\mathrm{C}(6)-\mathrm{C}(5)$ & $118.7(4)$ & $\mathrm{C}(14)-\mathrm{C}(13)-\mathrm{C}(12)$ & $121.2(4)$ \\
$\mathrm{C}(7)-\mathrm{C}(6)-\mathrm{C}(8)$ & $121.3(3)$ & $\mathrm{C}(13)-\mathrm{C}(14)-\mathrm{C}(9)$ & $121.1(3)$ \\
$\mathrm{O}(2)-\mathrm{C}(7)-\mathrm{C}(2)$ & $118.4(3)$ & $\mathrm{C}(16)-\mathrm{C}(15)-\mathrm{C}(12)$ & $113.1(4)$ \\
$\mathrm{O}(2)-\mathrm{C}(7)-\mathrm{C}(6)$ & $121.6(3)$ & $\mathrm{C}(16)-\mathrm{C}(15)-\mathrm{C}(17)$ & $114.7(5)$ \\
$\mathrm{C}(2)-\mathrm{C}(7)-\mathrm{C}(6)$ & $120.0(4)$ & $\mathrm{C}(17)-\mathrm{C}(15)-\mathrm{C}(12)$ & $111.7(4)$ \\
\hline
\end{tabular}



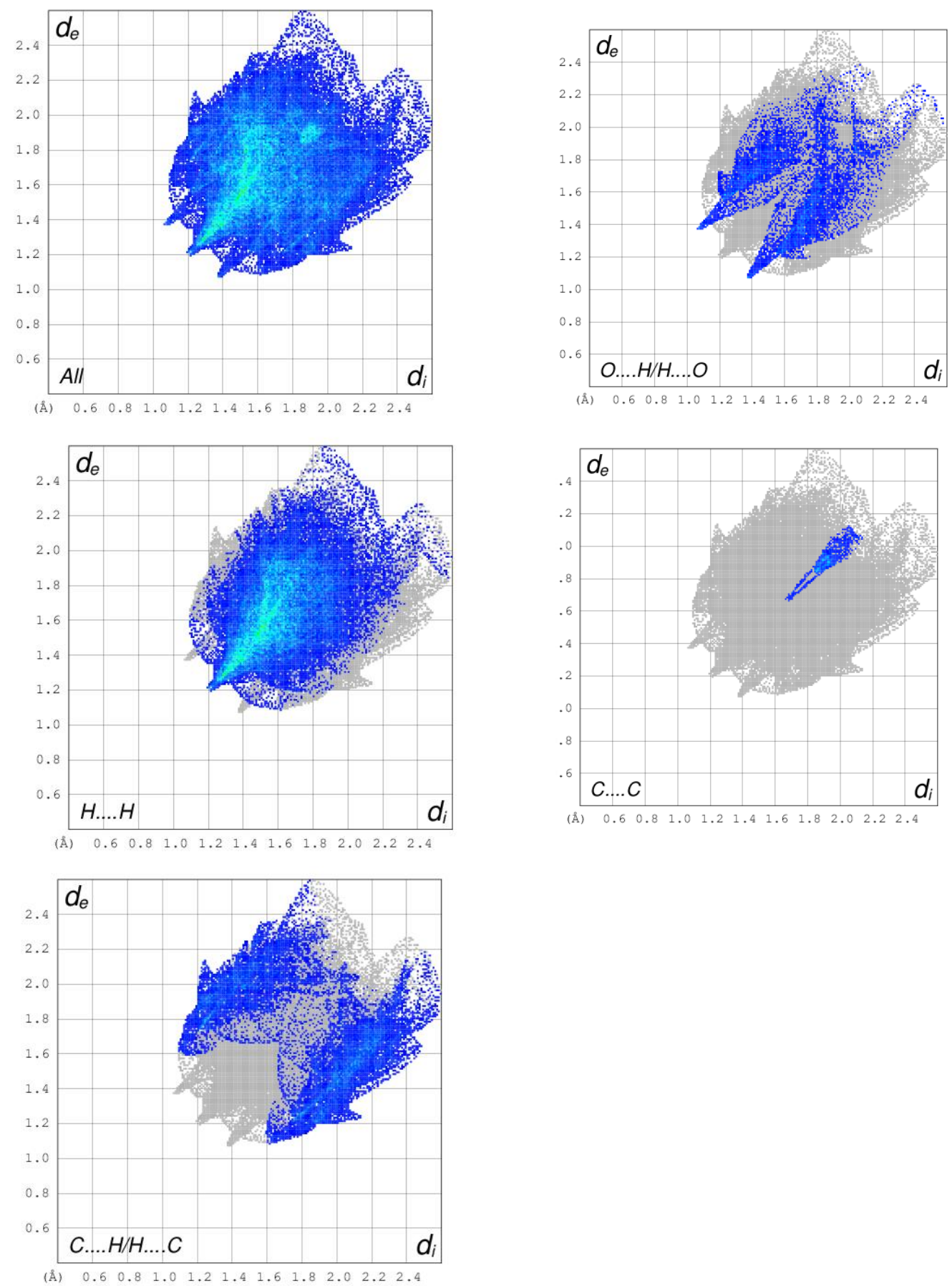

Figure 4. The 2D fingerprints plot of the compound showing the different intermolecular contacts.

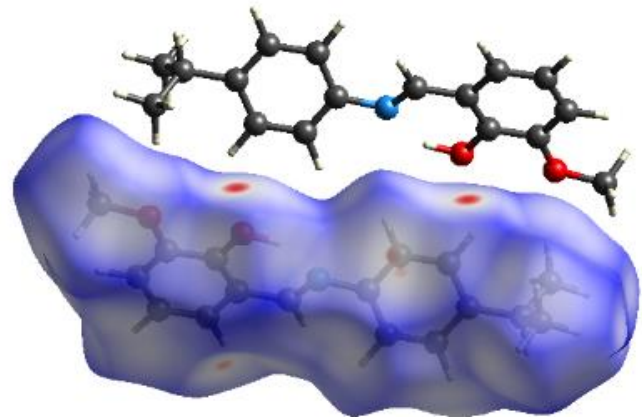

Figure 5 The $d_{n}$ surface of the compound.
UV-Vis. absorption spectra of the compound were studied in four different solvent at $5 \times 10^{-5} \mathrm{M}$ concentration. The compound showed two absorption bands in 250-400 $\mathrm{nm}$ range. The first band in the range of 250-300 $\mathrm{nm}$ can be assigned to $\pi-\pi^{*}$ electronic transition due to the $\pi$-electrons in the structure of the compound. The latter band in the range of 300-350 nm can be attributed to the $n-\pi *$ electronic transitions. The absorption bands slightly shifted to longer wavelengths when solvent polarity increases. In methanol, a weak broad absorption band at 400-500 $\mathrm{nm}$ range may be 
due to the shift from phenol-imine tautomeric form to keto-amine form [11]. o-Hydroxy Schiff bases can exist in two tautomeric forms (enol and keto forms) in both solutions and the solid state. The conversion from one tautomeric form to another depends on several factors such as temperature, the substituent structure and solvent polarity etc. The computational data indicates that the Gibbs free energies of these two forms are close and they can, easily, convert to each other. The enol-keto tautomeric transformation has an influence on their photo-physical and photochemical properties. Due to their intrinsic enol-keto tautomeric transformation also known as intramolecular proton transfer tautomerism, $o$-hydroxy Schiff bases have found applications in in higher energy radiation detectors, memory storage devices.

The compound showed a strong emission band when excited at around $300 \mathrm{~nm}$. The increase in solvent polarity caused a blue shift in the emission band of the compound and the highest intensity was observed in DMF solution. The absorption and emission maximums are given in Table 4. Absorption and emission spectra of the compound are shown in Figure 6.

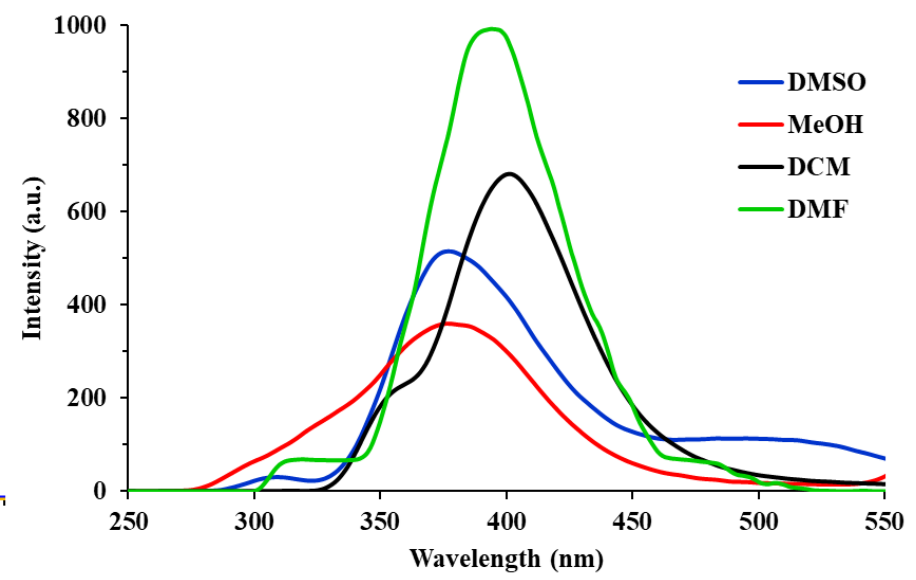

Figure 6. UV-Vis. and photoluminescence spectra of the compound

Table 4. UV-Vis. and photoluminescence data for the compound.

\begin{tabular}{ccccc}
\hline Solvent & $\begin{array}{c}\text { UV-vis absorption } \\
(\mathrm{nm})\end{array}$ & \multicolumn{2}{c}{ Photoluminescence } & $\begin{array}{c}\text { Stokes Shift } \\
(\mathrm{nm})\end{array}$ \\
\hline DMSO & 280,325 & 288 & Em.(nm) & 89 \\
$\mathrm{MeOH}$ & $280,320,450$ & 278 & 377 & 99 \\
$\mathrm{DCM}$ & $255,280,320$ & 334 & 377 & 67 \\
DMF & 275,325 & 302 & 401 & 92 \\
\hline
\end{tabular}

\subsection{DNA binding studies}

To examine the interaction between the synthesized molecule and FSdsDNA (fish sperm double strand DNA), UV-Vis. spectra of the compound was followed upon addition different concentrion of DNA. It was observed that the absorption band of the compound at around 250-300 $\mathrm{nm}$ increased incremental addition of the DNA solution (Figure 7). This increase showed a linear curve $\left(1 \times 10^{-5}\right.$ and $5 \times 10^{-5} \mathrm{M}$ DNA concentration range). Moreover, the addition of DNA to the solution of the compound (M) caused a red shift in the absorption bands. The DNA binding constant for the compound was then calculated using the equation given below.

$$
[\mathrm{DNA}] /(\varepsilon \mathrm{a}-\varepsilon \mathrm{f})=[\mathrm{DNA}] /(\varepsilon \mathrm{b}-\varepsilon \mathrm{f})+1 / \mathrm{Kb}(\varepsilon \mathrm{a}-\varepsilon \mathrm{f})
$$

where $\quad \varepsilon a=A o b s /[C o m p l e x], \quad \varepsilon a=A b s o r p t i v i t y$ coefficient of the selected wavelength of the complex and $\varepsilon b=$ Absorbency coefficient of wavelength selected by DNA of complex, respectively. In plots [DNA]/( $\varepsilon \mathrm{b} / \varepsilon \mathrm{f}$ ) versus [DNA], $K_{\mathrm{b}}$ is binding constant.

The binding constant with FSdsDNA was found to be as $K_{\mathrm{b}}=4 \times 10^{5} \mathrm{M}^{-1}$. The binding constant of the 
compounds are close to those standard DNA binders $\left(\mathrm{K}_{\mathrm{b}}\right.$ value of spermine and ethidium bromide are $2.1 \times$ $10^{5}$ and $8.1 \times 10^{4}$, respectively) [12-14].

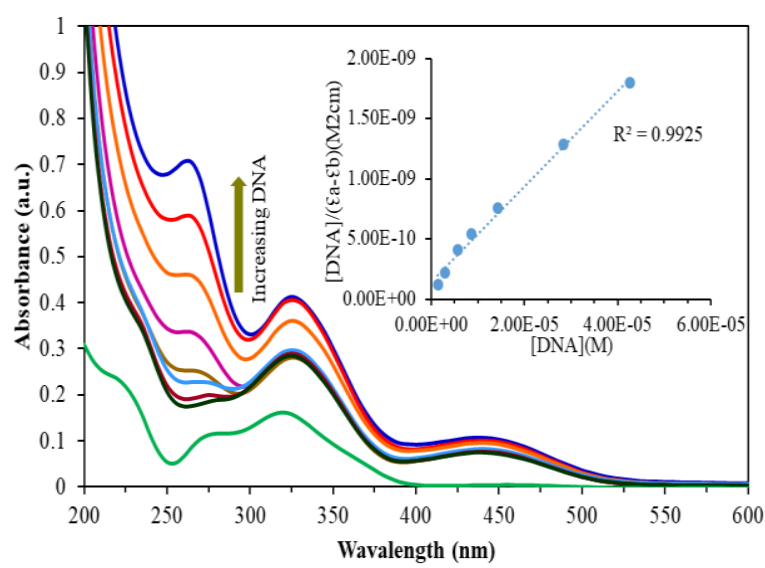

Figure 7. UV-Vis. spectra of the compound upon addition of FSdsDNA.

\section{Conclusions}

A new imine compound was prepared and its structure was characterized by spectroscopic and analytical methods. The structure of the compound was determined by $\mathrm{X}$-ray diffraction analysis and intermolecular interactions within the crystal structure were investigated by Hirshfeld surface analysis. Finally, the DNA binding properties of the compound was investigated by the spectroscopic method. The compound showed similar binding constant to those spermine and ethidiumbromide.

\section{Conflicts of interest}

The authors state that did not have conflict of interests

\section{References}

[1] Ceyhan G, Köse M., Tümer M. and Demirtaş I. Anticancer, photoluminescence and electrochemical properties of structurally characterized two imine derivatives. Spectrochimica Acta Part A: Molecular and Biomolecular Spectroscopy, 149 (2015) 731743.

[2] Al Zoubi W. and Ko, Y. G. Schiff base complexes and their versatile applications as catalysts in oxidation of organic compounds: part I. Applied Organometallic Chemistry, 31 (2017) 3574.

[3] Al Zoubi W., Kandil F. and Chebani, M. K. Solvent extraction of chromium and copper using Schiff base derived from terephthaldialdehyde and 5-amino-2-methoxyphenol. Arabian Journal of Chemistry, 9 (2016) 526-531.

[4] Kandil F., Al Zoubi W. and Chebani M. K., The synthesis and characterization of new Schiff bases and investigating them in solvent extraction of chromium and copper. Separation Science and Technology, 47 (2012) 754-1761.

[5] Köse M., Ceyhan G., Tümer M., Demirtaş I., Gönül I. and McKee V. Monodentate Schiff base ligands: Their structural characterization, photoluminescence, anticancer, electrochemical and sensor properties. Spectrochimica Acta Part A: Molecular and Biomolecular Spectroscopy. 137 (2015) 477-485.

[6] Oliveira-Brett A. M., Diculescu V. and Piedade J. A. P. Electrochemical oxidation mechanism of guanine and adenine using a glassy carbon microelectrode. Bioelectrochemistry, 55 (2002) 61-62.

[7] Kuetche V. An initio bubble-driven denaturation of double-stranded DNA: selfmechanical theory. Journal of Theoretical Biology, 401 (2016) 15-29.

[8] Sammriski E., Schwartz D. and Pablo J., A mesoscale model of DNA and its renaturation. Biophysical Journal, 96 (2009) 1675-1690.

[9] Sheldrick G.M., A short history of SHELX, Acta Crystallogr. Sect. A Found. Crystallogr, 64 (2007) 112-122.

[10] Sheldrick G.M., Crystal structure refinement with SHELXL, Acta Crystallogr. Sect. C: Struct. Chem., 71 (2015) 3-8.

[11] Gözel A., Kose M., Karakaş D., Atabey H., McKee V. and Kurtoglu M., Spectral, structural and quantum chemical computational and dissociation constant studies of a novel azoenamine tautomer. Journal of Molecular Structure, 1074 (2014) 449-456.

[12] Strekowski L., Harden D. B., Wydra R. L., Stewart K. D. and Wilson W. D. Molecular basis for potentiation of bleomycin-mediated degradation of DNA by polyamines. Experimental and molecular mechanical studies. Journal of Molecular Recognition, 2 (1989) 158-166.

[13] Chaires J. B., A thermodynamic signature for drug-DNA binding mode. Archives of biochemistry and biophysics, 453 (2006) 26-31.

[14] Strekowski L. and Wilson B. Noncovalent interactions with DNA: an overview. Mutation Research/Fundamental and Molecular Mechanisms of Mutagenesis, 623 (2007) 3-13. 